\title{
FORMAÇÃO GERAL: \\ BILDUNG NA ALEMANHA
}

\author{
GENERAL EDUCATION: \\ BILDUNG IN GERMANY
}

Sylvia Ewel Lenz ${ }^{1}$

\begin{abstract}
RESUMO: Apresento quadro geral sobre a educação e formação profissional alemã que, além do compromisso pelo bem comum, justificam o alto nível de seus trabalhadores e qualidade de produtos, tanto materiais quanto imateriais. Também enfatizo a quantidade e a variedade de universidades com vínculos na iniciativa privada, na pesquisa e intercâmbio acadêmico em nível doutorado e pós-doutorado, pois a dissertação ou estágio são exigências da graduação. Ressalto a reflexão teórica com a aplicação prática na formação de técnicos altamente qualificados, uma tradição que remonta às corporações de ofício no medievo. Também menciono a importância do patrimônio cultural na educação não formal que implica no hábito de frequentar museus, exposições e concertos. Por fim, abordo o zelo pela preservação da memória, as invenções e a disseminação do saber em vários formatos: impressos, sonoros, visuais e digitais.
\end{abstract}

Palavras-chaves: Disseminação. Capacitação. Profissionalização.

\begin{abstract}
Herewith I present a general frame about the professional German education and formation that apart from the compromise with the commonwealth explains the high level of their workers and quality of goods, material or non material. I emphasize the quantity and variety of universities and their contacts with private support, the Post and PhD university research and exchanges as Master degree is achieved in graduation. I appoint the use of theoretical reflection with practical application during the technical high qualified courses, a tradition which remotes to the medieval working corporations. I do also refer to the importance of cultural patrimony in non formal education which implies in the habit of frequenting museums, exhibitions and concerts. At last, I refer to the preservation of memory, the inventions and knowledge dissemination in several forms: pressed, audio, visual and digital.
\end{abstract}

Keywords: Dissemination. Capacity. Working World.

1 Doutorado em História pela Universidade Federal Fluminense. Professora de História Moderna e Contemporânea e do programa de mestrado em História Social da UEL. 


\section{Introdução}

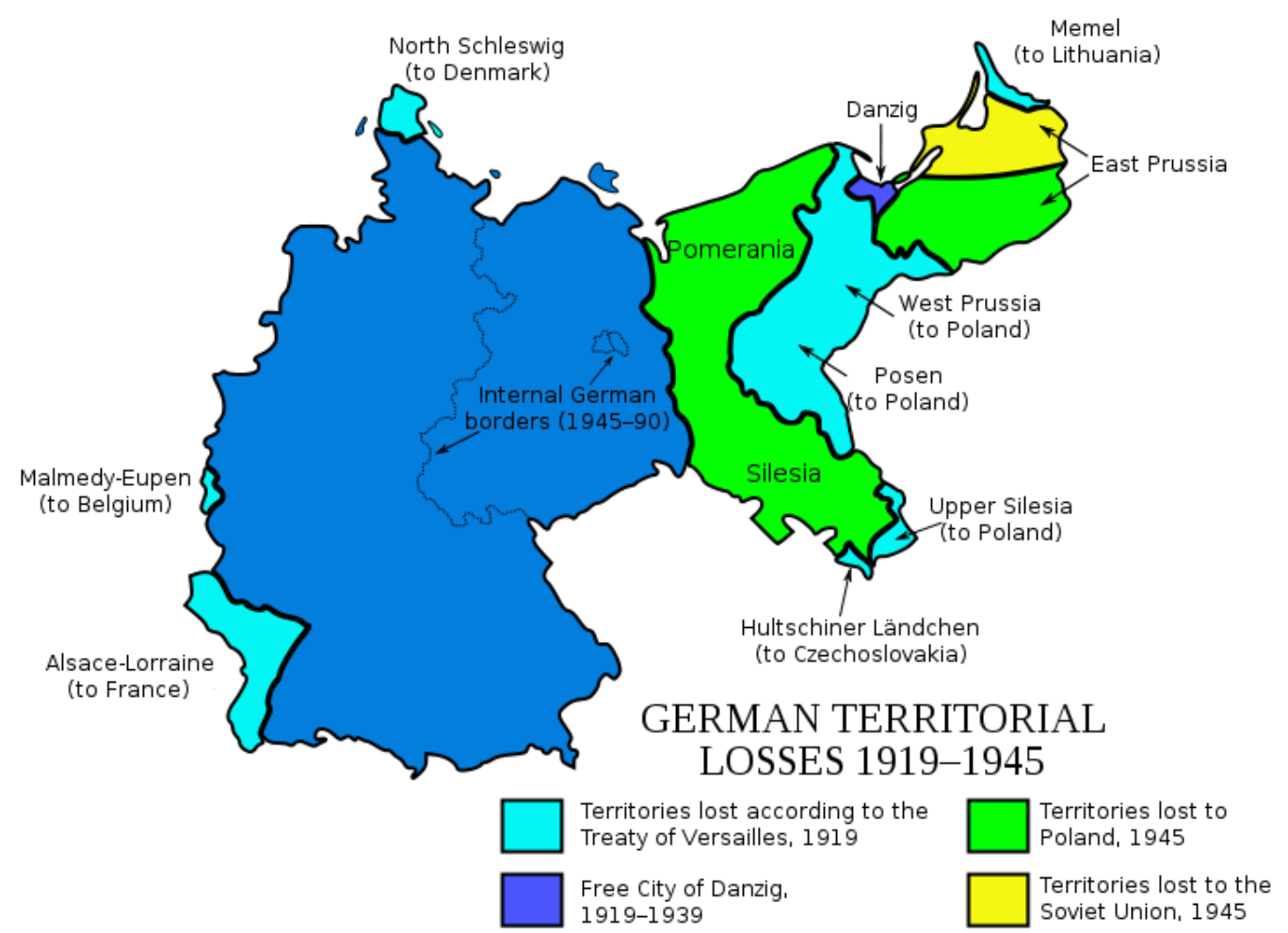

Mapa das perdas territoriais da Alemanha desde a sua unificação em 1871. WC: PD.

Complexa, a história da nação germânica, situada entre potências ultramarinas como França, Holanda e Reino Unido; e, territoriais como o império russo e otomano é bastante tortuosa e sofrida. Só para se ter uma ideia, o país foi cenário de cinco grandes guerras que implicaram em destruição do campo e de cidades, abalos econômicas, caos social e que foram. Apesar de sua tradição associativa, demorou séculos até os alemães se organizarem e se submeterem ao Estado centralizado, pois elites regionais tinham interesses confessionais, locais e dinásticos conflitantes.

Apesar da organização da sociedade civil quando o Estado foi consolidado em 1871, décadas depois o governo lançou a população à guerra suicida e mais tarde, o regime nazista terminou por aniquilar o Estado de Direito atropelando a cultura societária dos alemães. Antes de ser unificada, a cidades autônomas com status de micro-Estados dispunham do governante, eleito por uma assembleia, em geral formada por bacharéis e negociantes, ou seja, a classe abastada. Mas sob reinos e pequenos 
principados, eram as paróquias e comunidades aldeãs, posteriormente, associações e sociedades cumpriam funções sociais.

Após a derrota incondicional da Alemanha, em 1945, nem os aliados conseguiam administrar o país em ruínas, com os civis a sobreviver em meio a escombros, miséria, falta de víveres e de moradias, sob ocupação brutal dos vencedores. Fome, desespero, frio, doenças, miséria total para milhões de alemães desabrigados, desempregados e refugiados do leste. Em meio ao caos socioeconômico geral, os aliados elegeram administradores locais para reorganizarem o país em meio a escombros.

Em circunstâncias difíceis e extenuantes, estes recorreram à capacidade de se organizarem e juntos, cada qual responsável pela sua tarefa, trabalharam arduamente pela nação sem Estado. Em um ano, por exemplo, haviam reconstruído as estradas de ferro, fundamentais para deslocamento de bens e mercadorias. Aplicaram sabiamente os investimentos do Plano Marshall com moeda alemã - Deutsche Mark - DM impressa e cunhada nos EUA, culminando no "milagre econômico". Afinal, o povo alemão organiza-se para tudo: sociedades culturais e associações sociais e desportivas, clubes de caça e tiro! A iniciativa pessoal com visão coletiva promove a realização, em conjunto de ações em prol da vizinhança, do meio ambiente, enfim, do bem-estar geral.

Como este povo, em meio a tantos desmandos de dirigentes, nacionais ou estrangeiros, reergueu-se a ponto de liderar a economia europeia? Das justificativas, a educação, a tradição da ética do trabalho e o compromisso, embora seja um Estado que neste ano de 2012 completou 22 anos, a idade de minha filha... Ou seja, em menos de uma geração a região correspondente à antiga Alemanha Oriental, um terço do total do país reunificado, foi reformada, modernizada com ampla estrutura viária, novas instituições acadêmicas, culturais e artísticas, como a Ilha dos Museus em Berlim. Uma capital que já foi prussiana, imperial, ocupada, comunista e que voltou a ser capital de uma Alemanha arrojada, inventiva e atual: um país das ideias. 


\section{Trabalho técnico, conhecimento e divulgação}

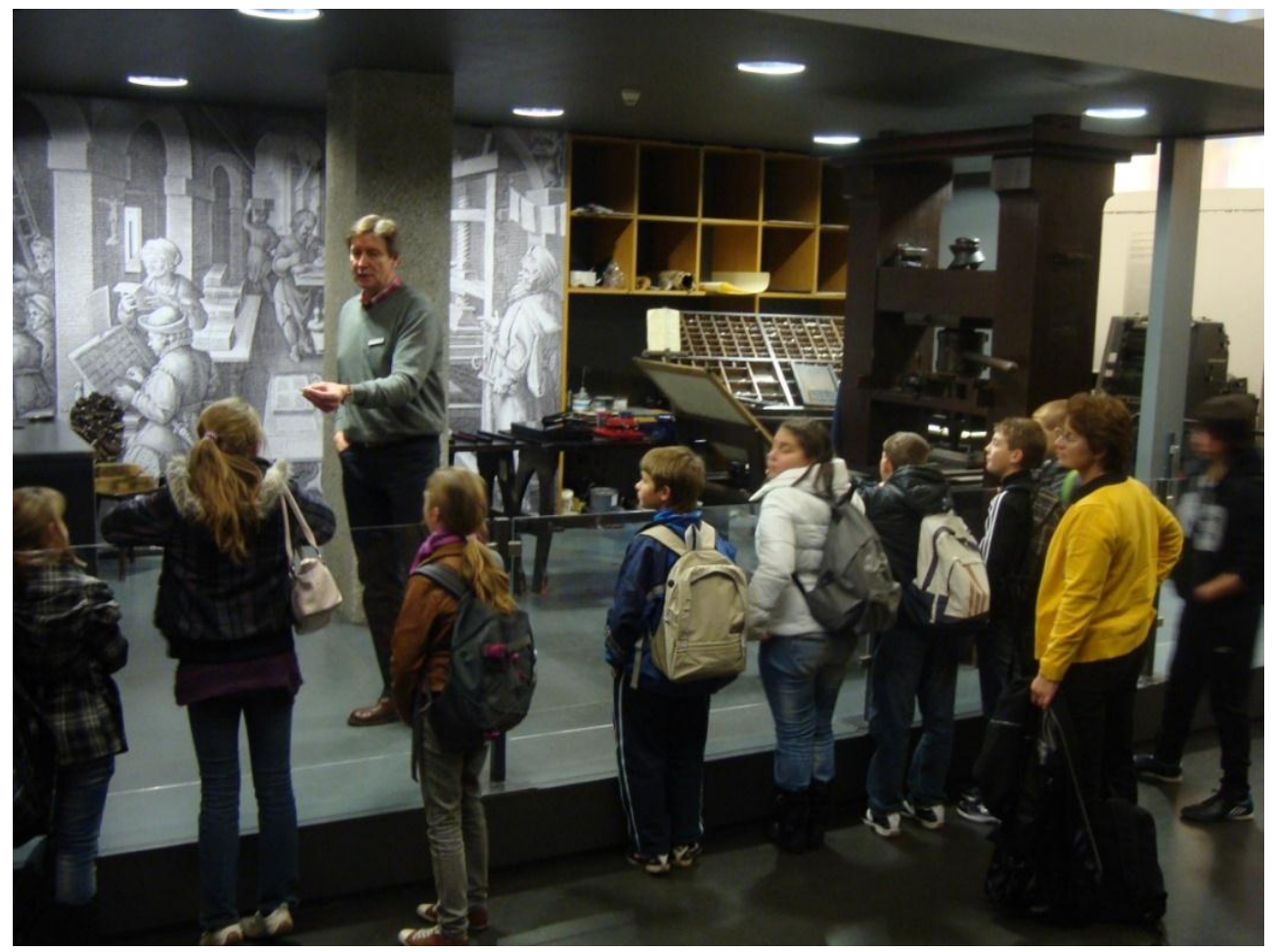

Explicação do instrutor sobre a prensa e o processo da impressão para alunos de escola. Museu de Gutenberg, terra natal do inventor, Mogúncia - Mainz. Foto da autora, 2010.

Relógio solar, ampulheta, ou mesmo velas marcadas para administrar o tempo religioso e laboral foram invenções para administrar o tempo, bem mais valioso limitado entre o nascimento e a morte. Não se sabe quem inventou o relógio mecânico, instalado no alto das torres e que regulava o tempo artificial em 24 partes, mediante o toque regular do sino - Glock, em alemão, Clock em inglês. Oposto ao tempo natural do campo, ditado pelo amanhecer e pelo anoitecer e das estações durante o ano, relógio e calendário aprimoraram o planejamento dos estudos e da produção nas cidades.

Em alguns prédios alemães, além do mecanismo altamente complexo dos órgãos, há calendários e relógios acoplados, astronômicos e astrológicos, que além de marcarem as horas e minutos, indicam a posição 
dos astros, o estado lunar, o período zodiacal e os feriados cristãos. Após a invenção do relógio de bolso por Pedro Henlein, século XVI, o indivíduo passava a carregar o tempo consigo, em mares e estradas, mantendo compromisso e horários.

Por outro lado, diz um provérbio alemão: "Basta juntar três alemães para que fundem uma associação"... Tal prática associativa - Vereinswesen - remonta às corporações de ofício no medievo, às paróquias religiosas na época moderna, às sociedades culturais, a partir do século XVIII. Tanto no campo como na cidade, camponeses e citadinos se reuniam para se ajudar na labuta diária. Nas paróquias luteranas havia serviços de ajuda mutua para doentes, viúvas, órfãos, além do ensino das primeiras letras ministrado pelo próprio pastor. As ordens profissionais zelavam pelo aprendizado, e pela viúva quando um de seus familiares falecia; promoviam reuniões e festas de confraternização. Mais tarde, diversas sociedades de letrados, atores, e músicos também visavam partilhar o conhecimento, usufruir da leitura de um bom livro, a atuação de uma peça teatral ou a execução de belas canções e melodias. Ou então simplesmente fundar um espaço aconchegante voltado para lazer, com livros e revistas, boa comida, música, quiçá com festas e bailes!

No passado, e principalmente no campo, quanto mais pessoas partilhassem do mesmo teto, mais braços para trabalhar, cuidar de plantação, colheita, ordenha, pastoreio. Desta labuta diária participavam mulheres adultas, enquanto crianças e idosos cuidavam das tarefas domésticas, incluindo fabricação de roupas e ferramentas. Na cidade, filhos de comerciantes eram iniciados nos negócios da família, o que explica empresas que remontavam ao século XVII. Os de artífices, tão logo entrassem na puberdade eram enviados para outra família onde aprendiam um ofício enquanto as filhas sem dote eram enviadas a trabalhar como domésticas - faxineiras, lavadeiras, babás e cozinheiras em casas de estranhos. Os filhos da nobreza alemã eram submetidos à dura disciplina nos estudos e nas armas, preparando-se para exercer algum cargo na alta burocracia, no serviço de militar com patente de oficiais para o comando do exército; e, em caso de vocação, seguiam o sacerdócio. 
No século XIX, as condições no campo eram árduas e, nas cidades, os artífices perdiam seu ofício para as fábricas, onde trabalhavam em ritmo extenuante, junto com mulheres e crianças, formando o proletariado. A nobreza empobrecida aburguesou-se com uniões matrimoniais lucrativas ou tornou-se, como outrora a veneziana e a inglesa, empreendedora. Enquanto isso, o segmento burguês ascendia socialmente por meio de riquezas, bens, boa conduta e família bem estruturada. Ou seja, a família tinha no pai, o provedor e chefe de família, na mãe, a exímia dona de casa auxiliada por serviçais, nos filhos, educados na ética cristã, a continuação dos pais, com o cumprimento de suas respectivas funções na sociedade.

No passado, o setor de artes e ofícios era realizado com mãos e ferramentas, aprendidos em família para atender a demandas da casa com objetos e consertos, além suprir a economia doméstica com a venda de produtos no mercado local. O ferreiro foi o primeiro profissional seguido pelo ceramista, oleiro, tecelão, pedreiro, marceneiro e que, no medievo, organizaram-se em corporações. A consolidação de manufaturas e fábricas durante a industrialização afetou o setor, que se recuperou durante o século XX diante das especificidades dos novos produtos. A complexidade tecnológica formou novos trabalhadores especializados em informática, eletricidade, hidráulica, e mecânica, além de outras áreas, como corporal e estética.

As corporações de ofício medievais promoveram, valorizaram e aperfeiçoaram as artes mecânicas formando grandes artífices. A imprensa e as artes gráficas modernas, por sua vez, também divulgaram estas técnicas, inclusive com a impressão de imagens ao lado dos textos. Já em países latinos valorizava-se o ócio monástico e o bacharelismo em detrimento do trabalho manual realizado por escravos, principalmente nas terras colonizadas além-mar. Até a irrupção das Grandes Guerras, a delicadeza dos acabamentos de móveis e instrumentos musicais, porcelanas, louças e copos de cristal alemães eram reconhecidos em toda Europa.

Os alemães destacam-se pela disseminação escrita do saber, pois desde Dürer e Gutenberg, aprimoram as técnicas de registro e de 
impressão gráfica. Em 1566 foi descoberta uma mina de grafite na Inglaterra e que amarrada a um pedaço de madeira servia para escrita. Em 1834, o Barão Von Faber assumiu a fábrica e aprimorou o produto que passou a ter formato hexagonal, escala de dureza e tom do grafite de modo que a Faber-Castell é mundialmente conhecida pela sua palheta multicolorida.

Durante séculos, a ponta afiada, de pena ou metal, servia para escrever com tinta, até a invenção da caneta tinteiro. Mesmo após a máquina de escrever, manual e elétrica, era de bom tom redigir notas e cartas à mão e exibir uma bela caneta como a Montblanc. Em 1906, uma firma de Hamburgo lançou a marca cujo nome remete à montanha mais alta da Europa, com cinco mil metros. Apesar da preeminência da informática, vários de seus objetos de luxo adornam os escritórios de executivos mais exigentes.

A partir de meados do século XIX, as imagens também começaram a ser reproduzidas fora das prensas, seja a fotografia sobre chapas de vidro ou os fotogramas em celulose que deflagraram a futura sétima arte, o cinema. Sons começaram a ser reproduzidos em caixinhas de música a partir da mecânica dos relógios, que faziam rodar cilindros de aço e cujas pequenas saliências esbarravam numa lâmina e liberavam as notas. A seguir, com base na tecnologia do telefone, foi inventado o fonógrafo, cujo suporte era um cilindro. Em 1887 um alemão emigrado para os EUA patenteou a gravação de ondas sonoras em um disco, revolucionando o mundo da música que poderia ser usufruída em casa, sem ter de ser tocada por alguém.

Emile Berliner voltou para a terra natal onde fundou a Deutsche Grammophon, unindo tradição e inovação ao promover a tecnologia da gravação de música erudita, marca registrada desta empresa até os dias atuais. O público amante da música, além de apreciar as salas de concerto, também podia usufruir desta arte sem sair de casas, nas frias noites de inverno; como ouvir em 1913, por exemplo, a 5a. Sinfonia de Beethoven, gravada na íntegra. Desde então, associa-se a gravadora à Orquestra Filarmônica de Berlim e ao seu mais famoso maestro, Herbert von Karajan, 
ou a Leonard Bernstein e a New York Philharmonic Orchestra, além de celebridades atuais. A partir do princípio dos radares, usados durante a Grande Guerra, os alemães desenvolveram as ondas de rádio e em 1926 foi inaugurada a primeira torre de radiodifusão em Berlim! Inúmeras antenas de transmissão foram instaladas pelo país para emitir ondas para os aparelhos receptores - futuros rádios. Ao tocar discos em suas programações, as estações de rádio divulgavam gratuitamente música fora das salas de concerto, direto para os lares... No século XIX fios de metal passaram a ser empregados em telégrafos, telefonia e na tentativa de gravar o som, mas neste caso mostraram-se inadequados.

Em 1928, Fritz Pfleumer empregou a fita magnética, e não um fio, para gravar áudio, usando papel com aço que, ao passar pelo campo magnético, emitia sons. Quatro anos depois as empresas BASF e a AEG Telefunken se uniram separando as funções: a primeira se encarregaria de melhorar a fita e a segunda de criar um aparelho de som. A invenção do poliéster, mais resistente e flexível, facilitou a invenção da atual fita magnética coberta de óxido de ferro, material que sobrava nos laboratórios. Dois anos depois, Manfred Von Ardenne realizou a primeira transmissão eletrônica de televisão, até 1935 foi possível aperfeiçoar os aparelhos que passaram a ter uma definição melhor, embora somente na década de 1950 ganhassem uso doméstico, cujo aperfeiçoamento fora interrompido pela Segunda Guerra.

O princípio da fita magnética foi então aplicado em vídeo e em banco de dados, nos computadores, não obstante serviu tanto para o mundo da música como da espionagem. Durante a Guerra Fria aparelhagem sofisticada de escuta seria empregada pela STASI - Polícia Secreta Estatal para controlar artistas e suspeitos no mais íntimo de suas vidas. Décadas após, os holandeses, leia-se Phillips, inventariam a fita K-7.

A fita magnética revolucionou as reproduções sonoras e depois viabilizou a gravação visual em VHS. Isso, sem falar no uso analógico dessas fitas na informática, antes da era digital. Aliás, para tanto, os fones de ouvido foram fundamentais para se ouvir sem ser percebido. Em meados de 1945, um engenheiro inventou-os talvez para atender à demanda por 
privacidade musical. Afinal, após anos de guerra sob o barulho ensurdecedor dos bombardeios aéreos, vivendo entre escombros e dividindo moradia com estranhos, não queriam mais ser incomodados muito menos estorvar os outros.

Ao final da década de 70, a Sony e a Philips produziam junto um disco que armazenasse uma hora de áudio, mas por causa da 9a. Sinfonia de Beethoven o tempo de gravação e reprodução foi estendido e os primeiros CD digitais lançados em 1982 visaram o mercado de música clássica. Depois, o MP3, uma invenção alemã, revolucionou o mercado sonoro com a possibilidade de baixar e comprar músicas locais e internacionais pela internet. Os fones também foram aperfeiçoados em termos acústicos e adaptados na forma até funcionarem sem fio ou ao da Língua Alemã com 27 mil verbetes em 187 páginas. Na 25a. Edição deste compêndio de fonética e gramática alemãs, o Duden possui 135 mil verbetes distribuídos em mais de mil páginas! Ele jamais imaginaria tamanho sucesso ao decidir unificar a ortografia alemã, pois até então, cada editora adotava uma regra própria. Vinte anos depois era obra de referência obrigatória e a Segunda Conferência Ortográfica considerou as sugestões de Herr Duden e unificou a ortografia alemã. No Instituto Bibliográfico Konrad Duden uma equipe de especialistas tornou-se responsável pela redação do dicionário. Atualizado, ele inclui palavras inglesas como Handy (celular) e regionais, como moin, o "tchau" do dialeto frísio.

Durante as quatro décadas de divisão alemã (1949-1990) o Duden foi publicado em versões diferentes nos dois países. Na comunista pelo Instituto Bibliográfico em Leipzig e na ocidental pelo Instituto Brockhaus em Mannheim. Após a Queda do Muro, em cada versão foram inseridos os vocábulos regionais e em 1991, a primeira edição unificada e cinco anos depois, o primeiro Duden publicado após a reforma ortográfica. A demanda é tão grande que consta na lista dos best-sellers, categoria de não ficção, pois o léxico também aborda aspectos como pronúncia, gramática, etimologia e estrangeirismos. Atualmente, o Duden oferece edições 
multimídia disponíveis em CD-ROM para plataformas Windows, Mac, Linux e aplicativos para IPhone, IPodtouch e IPad para Apple.

Mas todo este saber implica no domínio da linguagem e na sua clareza conceitual, caso contrário os saberes, tão arduamente conquistados, tendem a estancar e comprometer a cultura de uma nação. Neste sentido, os Irmãos Grimm, além da literatura popular e infantil, elaboraram o primeiro grande léxico da língua alemã cujos conceitos são acrescidos com citações clássicas. Esta obra foi continuada após a sua morte, completada em 1961 com 33 volumes. Para facilitar o manuseio, recentemente foi digitalizada por duas equipes na China e publicada em CD-ROM, além de estar disponível para consulta e atualização pela internet.

Além destas obras de referência, os alemães seguiram os passos dos vizinhos franceses cujos filósofos lançaram a Enciclopédia - a Paidéia, ou saber, em um sistema circular para sistematizar conceitos, proposta seguida pelos ingleses com a British Encyclopedia. Em 1808, Friedrich Arnold Brockhaus encantou-se com o Konversationslexikon adquirido na Feira do Livro de Leipzig. Mas como a obra incompleta amigos ajudaram-no a inserir vocábulos inexistentes e criando a Brockhaus Enziclopädie. Entre 1812 e 1816 foram vendidos dez mil exemplares, já que a obra atendia à sede pelo conhecimento mediante acesso ao mundo natural, das ciências, de artes e da vida pública.

Duzentos anos depois, a 21a. Edição da Enciclopédia Brockhaus tinha trinta volumes encadernados, 24.500 páginas impressas em papel couché, com 300 mil palavras-chaves, 40 mil imagens, mapas e gráficos. Este vasto o conteúdo também existe em forma digital, gravado em USB, acrescido de documentos originais e textos suplementares. Finalmente, DVDS multimídia com som e imagem, vídeos, animações e conteúdo interativo complementam a versão áudio-livro, com três mil verbetes sobre literatura, cinema, teatro, história e mundo natural.

O dicionário para línguas estrangeiras com capa amarela e com "L" em azul claro tem uma estória peculiar. Seu fundador, Gustav Langenscheidt realizou longa viagem cultural pela Europa como era costume entre os jovens e ia tudo bem até chegar a Londres, pois como não sabia 
inglês, sentiu-se solitário, afinal a linguagem é o elo social. Em 1856, Gustav criou o método Toussaint-Langenscheidt, feito para a aprendizagem da língua francesa e cujo sucesso foi tal que em 1881 chegava à 30a edição! Em 1861, lançou outro livro autodidata para aprender inglês; a partir de então, aplicou o modelo a outras línguas e em 1923, o último do gênero foi publicado em hebraico. Então, investiu no ramo de publicar dicionários e publicou do de alemão-francês, francês-alemão com quatro mil páginas! Em 1869, o Berliner Verlag investiu na elaboração do dicionário inglês-alemão, porém o orçamento previsto foi além do previsto. Em 1903, o filho iniciou a série de dicionários de bolso, com francês e inglês, mais barato e com maior demanda é o carro-chefe da editora.

Ele também criou o primeiro áudio-livro junto com a Deutsche Grammophon-Gesellschaft, ao editar discos para treinar a pronúncia da língua inglesa! Durante a Segunda Guerra, a editora, máquinas e suportes gráficos foram destruídos nos bombardeios e somente em 1947 o prédio foi reconstruído. No final dos anos 50 a empresa inovou com o segmento Viagem e Cartografia ao publicar guias poliglotas - em breve sucesso entre os viajantes de língua alemã. Mas após a construção do Muro de Berlim, diante do isolamento geográfico em meio à RDA, a empresa foi transferida para Munique.

Em 1947, antes da criação da RFA, jornalistas e fotógrafos fundaram Der Spiegel - revista investigativa cujo lema inteligente proclamava que "Os leitores do Spiegel sabem mais!" Desde 1952, o noticiário Tagesschau vai pontualmente ao ar e às $20 \mathrm{~h}$ adentra os domicílios alemães. Como o sinal também era captado pelas antenas do outro lado da Cortina de Ferro, os alemães tinham acesso às notícias do lado capitalista, como modas e inovações. O cenário da mídia alemã tem passado por grandes transformações devido à internet, mas apesar da multimídias, a Alemanha continua a publicar livros impressos com tiragem anual de 95.000 títulos.

Quase nove mil licenças vendidas para o exterior, principalmente nas feiras anuais de livro que acontecem em Frankfurt do Meno e Leipzig. A diversidade midiática é um fenômeno: trezentos e cinquenta jornais diários, duas mil e trezentas revistas, quatrocentas emissoras de rádio para os mais 
variados gostos musicais. Além disso, mais de duzentas emissoras de televisão, muitas locais, inúmeros acessos virtuais de informação.

Ao todo, mais de sessenta mil pessoas trabalham no ramo jornalístico. A Deutsche Welle fundada em 1953 é uma instituição de direito público financiada por impostos federais com programas abordam temas relevantes tanto sob perspectiva alemã como estrangeira e com três meios de comunicação: a DW-Radio, com sede em Bonn, transmite as notícias em alemão e inglês 24 horas; a DW-TV, em Berlim, em alemão, inglês, árabe e espanhol. A DW Internet, publicada em trinta idiomas diferentes, além de notícias atuais, apresenta informações culturais, sociais, econômicas, políticas, ambientais e fomenta o intercâmbio entre povos e culturas, além de divulgar a língua alemã e promover cursos.

Tantos atrativos científicos e intelectuais indicados nos itens anteriores despertam o interesse em aprender alemão e o Goethe Institut é a instituição oficial da Alemanha com 146 institutos espalhados por 89 países. Além disso, o instituto cultural oferece cursos variados nas principais cidades alemãs com atividades culturais e passeios. Universidades e Centros de Pesquisa recebem alunos de diversas partes do mundo, em cursos de graduação e pós-graduação. Quem deseja estudar lá, o Serviço de Intercâmbio Acadêmico Alemão - DAAD, representado nos principais países do mundo, encaminha o interessado para as universidades alemãs, incluindo cursos intensivos de língua alemã no Goethe-Institut de lá. A maioria entre 15 e 34 anos domina inglês, um terço francês e quase um quinto russo, língua franca nos países eslavos, afinal conhecer outra estrutura gramatical e conceitos estrangeiros amplia horizontes culturais e enriquece a língua materna.

\section{Famílias alemãs na educação informal}




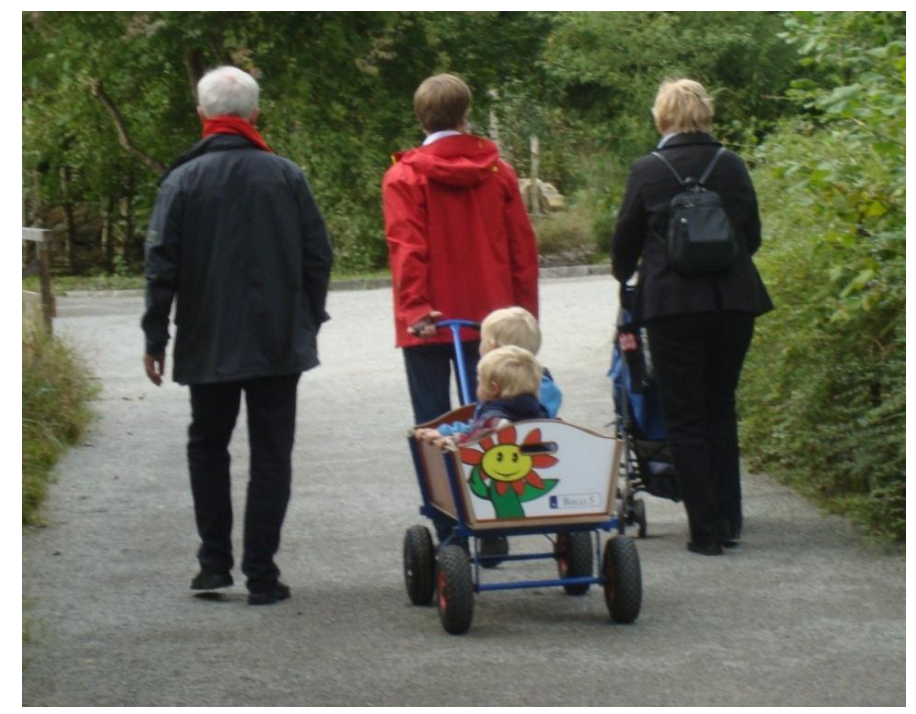

Família passeia com bebês pela Ilha de Mainau no Lago de Constança (fronteira com Áustria, Alemanha e Suíça) onde há o Jardim Botânico repleto de flores com borboletas e uma estufa tropical. Foto da autora, 2012.

A sociedade civil tem sido importante para resolver problemas locais ao fomentar a integração de membros da comunidade, promover a maturidade entre os jovens, ocupar o tempo livre dos aposentados. A participação social favorece grupos e pessoas que por inúmeros motivos não conseguem acompanhar as drásticas mudanças econômicas e tecnológicas, colocando-os à beira da marginalidade. Além disso, também inicia a socialização do jovem, valoriza a ação do idoso, ascendendo o espírito comunitário em uma sociedade de massas em que anonimato e impessoalidade podem anular o ser e sufocar o indivíduo.

Enquanto o jovem estuda, prepara-se profissionalmente e não adentra o mundo do trabalho e nem se interessa por política, a família, escola, amigos e colegas incentivam-no a se engajar socialmente. Assim, mais de um terço encontra-se dedicado socialmente em alguma atividade, sendo que metade participa de entidades esportivas - desde futebol a caminhadas. Um quarto dos jovens atua em instituições filantrópicas ao organizar atividades festivas, desportivas e sociais dentro da própria escola, em instituições culturais ou ainda até na defesa civil. Os demais participam com a família em paróquias confessionais, pois foram os primeiros cristãos se reuniam para praticar a caridade, inclusive com a instituição de asilos e hospitais.

História \& Ensino, Londrina, v. 18, n. 2, p. 249-280, jul./dez. 2012 
Mais tarde, quando frequenta os institutos superiores é que a juventude se interessa por questões políticas, mas isto após já terem passado por várias fases de socialização: familiar, com a vizinhança, escolar, civil e associativa. Quase a metade dos alemães vive em família; os demais residem sozinhos ou dividem a moradia com amigos, colegas ou até desconhecidos, já que não é ilegal sublocar quartos. Atualmente, a atomização do ser humano e seu anonimato em sociedades pós-industriais, de informação, fomentam o convívio íntimo da família. Isto demanda muito mais do que a paixão carnal e o amor romântico entre o casal, como também parceria, confiança e comunhão de interesses em prol da formação de um "porto seguro". O aconchego do lar, o trabalho doméstico compartilhado, a renovação com a chegada dos filhos, o calor humano das festas, o lazer na companhia de quem mais se ama, nada disto tem preço.

As profundas transformações socioculturais após a Segunda Guerra, com a divisão da Alemanha, o papel da mulher alemã na reconstrução material do país, a descrença na figura autoritária, geraram novas formas de estrutura familiar. O impacto da pílula e dos demais métodos anticonceptivos propiciou à mulher o controle sobre seu corpo, assim como o planejamento familiar. Essa revolução sexual promoveu a intimidade já na adolescência além das uniões, em caráter temporário, até a decisão pelo casamento oficial com a intenção de permanecerem unidos até que a morte os separe. Hoje, a maior parte das famílias ainda é nuclear, em que o pai é o provedor principal, embora cerca de $60 \%$ das mães também trabalhem talvez em jornadas e salários menores, e ambos partilham do trabalho doméstico.

A família alemã ideal é formada por pais com duas crianças, um menino e uma menina, embora muitos casais, após o primeiro nascimento, optem pelo filho único. Raramente costumam ter mais de três filhos. Uma minoria gosta de ter três ou mais filhos, situação incentivada por bolsas do governo para a cada criança. Em função de um tempo maior para a formação dos jovens, as uniões só costumam ocorrer após certa estabilidade econômica e profissional, ao menos de um dos cônjuges. 
Seguindo essa tendência, hoje, metade das mulheres se torna mãe já com os cabelos grisalhos - ou seja, a maternidade ocorre bem depois dos trinta anos.

Há poucas décadas o relacionamento entre pais e filhos, tem passado por grandes mudanças, porém, atualmente as novas famílias são bem diferentes das gerações anteriores, nas quais o pai era autoritário e a mãe reprimia as emoções, de modo que juntos educavam as crianças com rigor e frieza. Afinal, os alemães prezam a vida no âmbito privado para ser desfrutada da melhor maneira possível, com harmonia, diálogo e participação efetiva. Neste sentido, os pais priorizam o diálogo aberto, a convivência com as crianças, seja brincando, levando a passeios ou prestigiando-as em suas apresentações escolares, educadas com liberdade condicionada.

Desde cedo, o cotidiano é regido por regras de convívio dentro e fora de casa, basta ver as inúmeras placas de "Proibido" bem visíveis em lugares públicos. O adensamento populacional em uma sociedade altamente complexa e desenvolvida como a alemã implica na consideração, no respeito em relação a horários e ao espaço privativo de cada um. Raramente os vizinhos batem à porta sem antes telefonar e quando pegam algo emprestado devolvem-no limpo e completo, sem peças faltantes. Pois sabem que se não agirem assim, perdem a confiança e deixarão de ser atendidos na vizinhança. A polidez também faz parte das atitudes que amenizam as relações entre os estranhos, como o 'por favor' - Bitte; o 'obrigado' - Danke; o 'bom dia', 'boa noite' - Guten Tag, Guten Abend, ou a expressão - Grüss Gott, 'Salve Deus' - usada, principalmente no sul do país tanto para desejar bom dia como para dar um alô carinhoso.

Entre casais, o amor é tão importante quanto à parceria e a cumplicidade entre eles, sentimento que sustenta a relação a médio e longo prazo, depois que passa o encantamento inicial e a vida a dois entra se torna rotineira. Raramente as relações duram a vida inteira, mas elas tendem a ser monogâmicas uma vez que a fidelidade é muito valorizada e em geral os casais preferem romper a manter relações extraconjugais. Uma vez que ambos trabalham fora, as tarefas de casa costumam ser 
partilhadas e bem definidas, em geral, levando em conta o perfil do homem e da mulher já que o custo de uma diarista, paga por hora, é muito alto. Assim, raros são os casais ou as famílias que dispõem de uma auxiliar. A mulher zela pela arrumação: lava, passa, cozinha e divide a faxina com o parceiro enquanto ele faz a conservação da casa e do jardim, reparando as coisas e até pintando paredes. No entanto, esse quadro varia conforme a faixa etária dos casais.

Com a chegada dos filhos, ao pai cabe prover roupas, brinquedos, formação dos filhos. E à mãe, que em geral abre mão do emprego em período integral ou parcial, o serviço doméstico. Somente famílias de alta renda ou domicílios com duas ou mais famílias contratam uma empregada doméstica, e mesmo assim, por meio período. Por isso, os pais delegam tarefas aos filhos, que contribuem ao limpar e arrumar o quarto, trazer a roupa para lavar, guardá-la no armário, cuidar dos bichos e do jardim.

Desde pequena, a criança é educada para seguir os horários das refeições, do banho, de dormir. Assim, há regras ditadas e debatidas, horários para estudar e brincar, para as refeições consideradas fundamentais para reunir toda família, pela manhã ou à noite. Essa rotina torna a criança apta para lidar com o tempo, preparando-a para os inúmeros compromissos que terá na vida adulta. Assim, tudo tem o seu tempo: convívio familiar no lar, momento íntimo do casal; atividades públicas no trabalho, na escola e em associações; tempo de recolhimento pessoal para se dedicar ao que interessa.

E tudo tem o seu lugar e, se possível, assim como o casal tem seu quarto, cada filho terá o seu também. Suítes não são comuns e todos partilham de um banheiro só, pois o lavabo é para visitas. Na entrada das casas ou dos apartamentos há um vestíbulo ou um pequeno corredor, que serve para pendurar casacos, gorros e cachecóis, e acomodar guardachuvas, botas e sapatos. Dentro de casa, os residentes tiram os sapatos e calçam pantufas, evitando trazer a sujeira da rua para dentro de casa. A copa-cozinha ou a sala de jantar é o lugar que agrega a família, pois é lá que ela se reúne para as refeições, para um chá ou um café entre uma tarefa e outra. Na geladeira, imãs coloridos prendem recados e lembretes. 
Em uma das paredes, alguns pais estendem um cordão onde penduram desenhos e pinturas das crianças, conferindo descontração ao ambiente. Na sala de estar, mais formal e arrumada, a família se reúne para assistir televisão, jogar cartas ou mover peças de tabuleiros, ou ainda simplesmente para ler ou ouvir boa música. E na garagem ou no porão, são guardadas bicicletas, ferramentas e tralhas domésticas...

Os avôs também participam da vida familiar, aliviando um pouco a tarefa dos pais que, só assim, podem sair a dois, ir a restaurantes, encontrar amigos. O avô costuma fazer alguma atividade com as crianças como praticar esportes e a avó prepara alguma guloseima especial para a hora do lanche. Todos eles interagem brincando, contando estórias, ouvindo as crianças, cuidando dos animais domésticos com eles. Os bichos mais estimados na Alemanha são, em primeiro lugar, os gatos, depois os hamsters e, finalmente, os cachorros, talvez porque para eles, os proprietários devam pagar certas taxas. Pássaros em gaiolas e peixes em belos aquários figuram ao lado de bichinhos menos comuns como coelhos, tartarugas e porquinhos-da-índia.

Assim, o adolescente ganho autonomia, cuida de si mesmo e de seus pertences, prepara o lanche, faz compras no mercadinho do bairro. A maioria dos jovens com a idade entre 12 e 21 anos sempre morou com os pais e afirma ter uma relação de confiança com eles. Enturmam-se com colegas da escola e amigos vizinhos para passear ou sair à noite. São pragmáticos, socialmente engajados e pretendem ser prósperos e bem sucedidos. Segundo dados de 2005, o nível de qualificação escolar subiu bastante desde a última década: após o ginásio, cerca de $60 \%$ ingressam em uma escola ou no sistema dual de formação profissionalizante, $37 \%$ se dirigem a alguma instituição de nível superior - técnico ou universitário, e somente $3 \%$ largam a escola sem estar qualificados para o mercado de trabalho. Os pais, por sua vez, também vivem uma segunda puberdade, viajam sem os filhos com mais tempo para a relação a dois, inclusive erótica.

Idosos e anciãos assegurados pelo sistema médico e previdenciário que zelam para pela saúde e ocupação numa fase em que visam a desfrutar 
a vida. Anualmente, eles se encontram com antigos colegas de escola, de universidade ou do trabalho para relembrar aquela época. Os seniores costumam ter, em bares e restaurantes, mesas fixas em determinados dias e horários para encontros em que comem e bebem. Também praticam esportes, caminham muito, pedalam suas bicicletas pela região - bem servidas por ciclovias - quando há tempo bom, viajam em grupo e, quando cansam, embarcam no vagão especial para bicicletas e seguem de trem... Eventualmente, ajudam a cuidar dos netos quando os pais trabalham fora, mas raramente cabe-lhes a criação dos mesmos.

A longevidade da população alemã, o casamento e os nascimentos tardios promovem o convívio familiar entre até quatro gerações e por mais tempo do que no passado. Pais e filhos já adultos se visitam pode até ocorrer que, na morte do pai, o filho ou filha solteiro ou separado, venha a morar com a mãe viúva. Muitos idosos doentes recebem cuidados em casa, outros moram sozinhos até que, incapazes, são levados a retiros enquanto o governo administra os bens, o enterro, e depois a herança. Quanto aos parentes, as relações são menos próximas, mais reservadas e menos invasivas, de modo que as diversas famílias só se encontram em casamentos, batizados, enterros, e nas grandes festas. Os alemães têm um cuidado especial com a infância a ser vivida no tempo certo, com brinquedos, vestimentas e brincadeiras apropriadas para cada faixa etária.

Em finais de semana chuvosos não falta o que fazer dentro de casa: jogos de baralho ou de tabuleiro, autoramas, hobbies diversos como montar aviões e navios em miniatura, micro ferrovias ou mesmo casas e cidades com blocos de madeira ou lego. O mundo infantil não seria nada sem os bichos de pano e pelúcia, criados pela Sra. Steiff, uma costureira com paralisia infantil que começou a costurá-los enquanto os irmãos zelavam pela venda. O sucesso de vendas dos bichinhos como o Elefäntle que, só em 1886, vendeu mais de cinco mil peças, e culminou com o Teddy Bear, ursinho que completou cem anos em 2002.

Crianças e adultos demonstram paciência e persistência ao montar quadros de quebra-cabeças: quanto menores as peças, maiores os quadros, obras de arte. Os pais começam a ensinar os filhos a fazer a manutenção 
dentro de casa ao repararem brinquedos, bicicletas e, mais tarde, o carro já que a mão de obra é cara, cobrada por hora de trabalho. Talvez esse hábito remonte à tradição dos artífices, cujos trabalhos - marcenaria, construção civil, ferro fundido, vidro dentre outros - se tornaram famosos pela qualidade. O adolescente pode confeccionar a casinha do hamster, montar os trilhos e ligar os fios do trenzinho elétrico andar. As meninas fazem trabalhos manuais com linhas e agulhas, tapeçarias, bijuterias e os menores rabiscam, modelam massinhas, enfim, pintam o sete!

Há quarenta anos, bonequinhos com $7,5 \mathrm{~cm}$ de altura, feitos de plástico colorido, com carinha sorridente, cabeça, braços, pernas e até mãos móveis encantam crianças e adultos. Primeiro surgiram os rapazinhos, depois os homens e hoje as crianças completam a família Playmobil com os personagens mais variados, que conta, em sua enorme galeria, com guardas romanos, cavaleiros, piratas, soldados, bombeiros, trabalhadores, ou jogadores de futebol, contribuindo para a criatividade de meninos e meninas, que inventam contos e os inserem no cotidiano.

Em dias ensolarados, as crianças brincam nos jardins que dispõem de brinquedos apropriados para elas: balanços, escorregadores, pula-pulas, ou então vão para os parques verdes onde também há balanços feitos com pneus, gangorras, e outros brinquedos feitos com madeira, molas de carro e cordas. As famílias dispõem de bicicletas e com elas também organizam excursões, levando bebidas e lanches a serem saboreados à beira de águas, ou em campo aberto, pois os alemães apreciam os raros dias ensolarados. No inverno a família patina em pistas congeladas, joga bolas de neve, faz bonecos de neve com direito a nariz de cenoura e até gorros velhos na cabeça... Enfim, os pais preservam a infância dos seus filhos proporcionando brincadeiras lúdicas e convivência saudável entre eles e com as famílias vizinhas, evitando que as crianças percam este curto período de vida em frente aos programas de televisão, internet ou jogos virtuais.

Com clima temperado: de morno a quente, no verão; frio e gélido no inverno; chuvoso na primavera e outono, os alemães dispõem de diversos tipos de lazer, dentro e fora de casa. Eles se programam para tudo: visitar 
museus e exposições de arte, passear pela cidade, conhecer restaurante, bar, sorveteria ou café, ir a um evento, ou visitar amigos. Ou ficar em casa, com a família, assistindo a filmes, fazendo artesanato ou jardinagem, lendo um bom livro ou apenas ouvindo boa música. Também viajam em família, sozinhos, em pares, ou em grupos pelo país, para conhecer melhor sua própria origem, além de também buscar contato com novas culturas.

Durante o inverno as noites são longas e os dias curtos, o alvorecer ocorre em torno das nove horas da manhã e, raramente, o sol desponta através das nuvens, entre chuva, neblina e nevasca, e já se põe às quatro da tarde. Mesmo com a casa aquecida, o conforto, as bebidas e os alimentos estocados, parte da população fica depressiva. Mais uma motivação para valorizar o convívio harmonioso entre os familiares, por meio de atividades conjuntas, a fim de obter diversão.

Em dias ensolarados e com neve, bom mesmo é sair bem agasalhado para brincar em parques e jardins, jogar bolas de neve uns nos outros, fazer o famoso boneco de neve. Também se pode patinar no lago congelado ou simplesmente caminhar ao ar livre, pois respirar o ar fresco sempre faz bem ao corpo e à alma. Assim que o clima fica um pouco mais ameno, mesmo que nublado, vale a pena dar um passeio pelas redondezas, de bicicleta ou de carro.

Mesmo em dias nublados, ou com chuva fininha, as famílias sarem para desfrutar momentos de lazer com a família, uma oportunidade para o homem ser parceiros da mulher e pai presente; para a mulher, ser companheira do marido, e ambos estarem próximos dos filhos. Jovens e adultos solteiros, casados, grupos de idosos, realizam passeios pela redondeza ou viajam de carro, bicicleta ou trem pela Alemanha. Se o dia está ensolarado, a ordem é ir para parques e praias, tirar as vestes, quedar-se deitado só com a roupa de baixo, para render-se ao calor do deus Hélio.

Devido à temperatura gélida do mar, costuma-se ir para praias fluviais e lacustres onde venta menos e que ficam em áreas verdes, devidamente estruturadas para visitantes. Lá, as crianças correm, empinam grandes pipas com motivos diversos, brincam e se cobrem com areia, 
jogam bola com os pais, enfim, divertem-se muito. Os locais de lazer público dispõem de restaurantes, bares e cafeterias para atender a jovens e adultos, famílias e crianças. Lá, pode-se comprar e levar o lanche, para comer na grama ou na beira do rio. O convívio é pacífico, ninguém deixa lixo pelo chão, respeita-se o espaço de cada um.

Casais namoram, grupos fazem churrasco em casa ou em locais próprios, outros preparam o piquenique, hábito importado dos vizinhos franceses. Qualquer snack ou refresco não é barato, de modo que é comum as pessoas carregarem garrafas térmicas, água e refrigerantes, além de frutas e sanduíches para o lanche ao ar livre. Os alemães pensam em tudo e resolvem pendências não de forma individualista, mas coletiva. Em decorrência dessa postura, são membros de várias associações em prol do lazer. Por isso, há casas para uso diário, sem pernoites, com banheiros, panos, toalhas, cozinhas equipadas com panelas, pratos, copos, talheres, além de um recinto para descansar. A regra é simples: usar e usufruir do lugar, deixá-lo tão limpo como antes, depositar o lixo em local destinado, fechar as janelas e trancar a porta ao ir embora. Ou seja, a casa fica pronta para ser usada pelos próximos associados, familiares ou amigos.

No ambiente de trabalho, os colegas visam a colaborar e cooperar e saem para tomar um chope ao final do dia e celebrar alguma notícia boa na empresa. Nesse sentido, pequenos gestos são importantes, como presentear com flores, lembrar aniversários, convidar para um momento de celebração mesmo que seja após o expediente de trabalho, sempre brindando um Prosit! É certo que nem sempre o ambiente competitivo de hoje favorece a tanto, mas a tendência herdada desde as antigas corporações de ofício permanece como cortesia entre eles. Afinal, a realização profissional é um dos maiores valores para os alemães, não só para ascender socialmente, acumular bens e obter conforto, mas acima de tudo para se sentir inserido, aceito, valorizado pela sociedade em que vive.

Para tanto a educação não formal como a vivida no cotidiano de viver artes, música e culturas em museus, exposições, parques, feiras e festivais é promovida pela família. Mas a educação formal continuada é fundamental em uma sociedade tecnológica e de informação altamente desenvolvida 
como a alemã. A seguir, apresento o sistema de ensino que vai do Jardim de Infância à formação de adultos.

\section{Educação para o trabalho, capacitação e aperfeiçoamento}

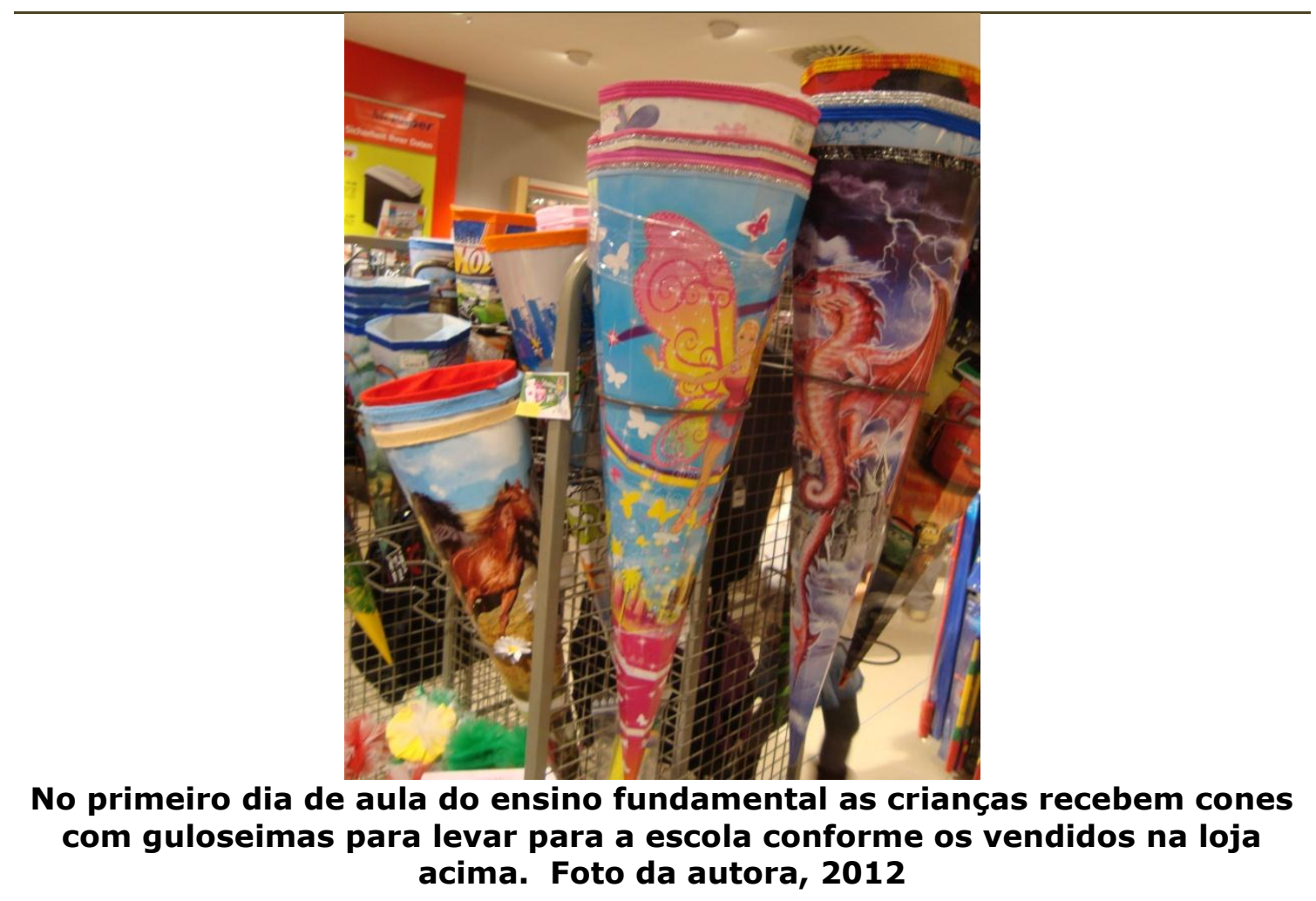

Em 1837, Friedrich Fröbel criou o Kindergarten - jardim da infância, como espaço lúdico e temporal entre a família e a entrada para a escola, onde deveriam ser cuidadas como plantas em um jardim. Crianças a partir dos três anos aos seis anos de idade são estimuladas a interagirem por meio de estímulos lúdicos, a desenvolverem sensibilidades musicais, a realizarem tarefas conjuntas. Nessa etapa escolar não se pretende alfabetizar nem ensinar conteúdo programático, mas estimular a criatividade infantil mediante diversas atividades artísticas. No jardim da infância - Kindergarten elas cantam, dançam em rodas, tocam alguns instrumentos fáceis como triângulo, tambor, flauta, enfim, divertem-se! 
Afinal, terão a vida inteira para estudar, seguir as exigências culturais em uma sociedade altamente complexa.

Complexo, porém lógico, o sistema escolar alemão abrange diversas etapas a começar pela Escola Fundamental - Grundschule com quatro anos a seis anos (depende do estado) em tempo parcial para crianças de sete aos dez onde aprendem língua alemã, história geografia, aritmética, música, arte, desenho, educação física e instrução religiosa. Terminada esta fase, pais e mestres escolhem o tipo de escola secundária que a criança vai frequentar: Colégio Principal - Hauptschule, Liceu - Gymnasium, Colégio de Ensino Geral - Realschule, Colégio Integrado - Gesamtschule. A escolha do tipo de escola é feita segundo os seguintes critérios: recomendação escolar, escolha dos pais, nível do desempenho do aluno e/ou exame de admissão.

A Escola Principal - Hauptschule dura de cinco a seis anos e visa a preparar os alunos para a escolha adequada profissão - Berufschulen onde aprenderão a exercer um ofício pelo sistema dual em que tanto tem dois dias de aulas teóricas e dois de aprendizes no lugar de trabalho. O currículo escolar abrange: Alemão, Língua Estrangeira, Matemática, Física, Química, Biologia, Geografia, História, Mundo do Trabalho, Religião, Música, Arte, Política e Educação Física com trinta ou mais horas-aula semanais. A autora viu como um jovem ainda imberbe que, aos 16 anos atendia em uma loja da Lego com boa educação e entendimento do assunto.

O Colégio de Ensino Geral - Realschule tem currículo escolar semelhante ao da Escola Principal exceto pela inclusão de mais uma língua estrangeira, maior rigor no ensino de Matemática, além de abordar temas de economia, artes liberais e técnica tratar de economia. Ao final do curso o aluno ingressa em escolas vocacionais como a Escola Técnica Superior ou em classes finais do Colégio Superior do Liceu - Oberschule..

O Liceu dura nove anos com disciplinas obrigatórias como: Alemão, duas Línguas Estrangeiras (inglês, a segunda depende da disponibilidade de professores, mas pode ser latim, espanhol, russo ou francês), Literatura, Matemática, Ciências, Ciências Sociais (História) Tecnologia, Sociologia, Arte, Música, Filosofia, Instrução Religiosa, Economia, Física, Química, 
Biologia. As optativas são: Pedagogia, Psicologia, Sociologia, Assuntos Legais, Geologia, Astronomia, Informática, Estatística. Uma vez passado no complexo e difícil exame do Abitur, o aluno está apto a ingressar na faculdade conforme a nota adquirida.

Já o Colégio Integrado procura combinar os programas educacionais, qualificações e certificados de todas as formações secundárias com aprovação automática dos alunos que só é reprovado com autorização dos pais. Também há escolas particulares católicas, protestantes, de associações ou mesmo de pessoas físicas com intuito empresarial, autorizadas pelos governos estaduais.

A formação dos professores hoje exige dois cursos universitários, na área e outro em Pedagogia, após o qual devem passar por exames estatais, o primeiro teórico e o segundo, após dois anos de estágio probatório. Quanto à instrução religiosa é bem diversificada, mais católica ao sul, voltada para ética protestante ao norte, ou voltada para o islã, conforme a tipologia de alunos da escola.

O leque de cursos oferecidos por estas escolas para adultos - Colégio Superior Popular - Volkshochschule -VHS é impressionante assim como o interesse e demanda pelos mesmos. Elas foram fundadas ao final do século XIX e são administradas pelas municipalidades, e diferem bastante entre si. Tanto atendem a várias necessidades: a simples ânsia pelo saber, como forma de ocupar o tempo após o trabalho, para se aperfeiçoar, atualizar, ou mesmo capacitar para outra profissão. Ou seja, não só para os alemães, como para os europeus em geral, a formação é contínua, dura a vida inteira de modo a manter o cidadão a par das constantes transformações socioculturais e técnicas nesta economia globalizante.

Antes de abordar as universidades, ressalto que a as escolas também fomentam o ensino não formal ao realizar, anualmente, excursões com as classes para visitar parques naturais, cidades históricas e patrimônios culturais. Em geral cada classe é acompanhada por dois mestres e se hospedam na cadeia, hoje internacional, dos Deutsche Jugendherberge $\mathrm{DJH}$, os Albergues da Juventude. 
Aliás, o idealizador deste tipo barato de hospedagem foi Herr Schirmann, um mestre que excursionava com seus alunos durante as férias e foram surpreendidos por uma forte tempestade antes de chegar à próxima hospedaria. Como estava no campo, abrigaram-se num barracão para onde os camponeses trouxeram feno para forrar o chão e leite para alimentá-las. Então o Lehrer teve a ideia de instalar beliches em áreas subutilizadas, como antigos casarões, alpendres e até castelos abandonados. Isto faz já um século! Após a Segunda Guerra, esta iniciativa foi retomada para integrar jovens de diversos lugares, assim como para hospedar alunos das escolas.

\section{Universidade: aprendizagem e pesquisa}

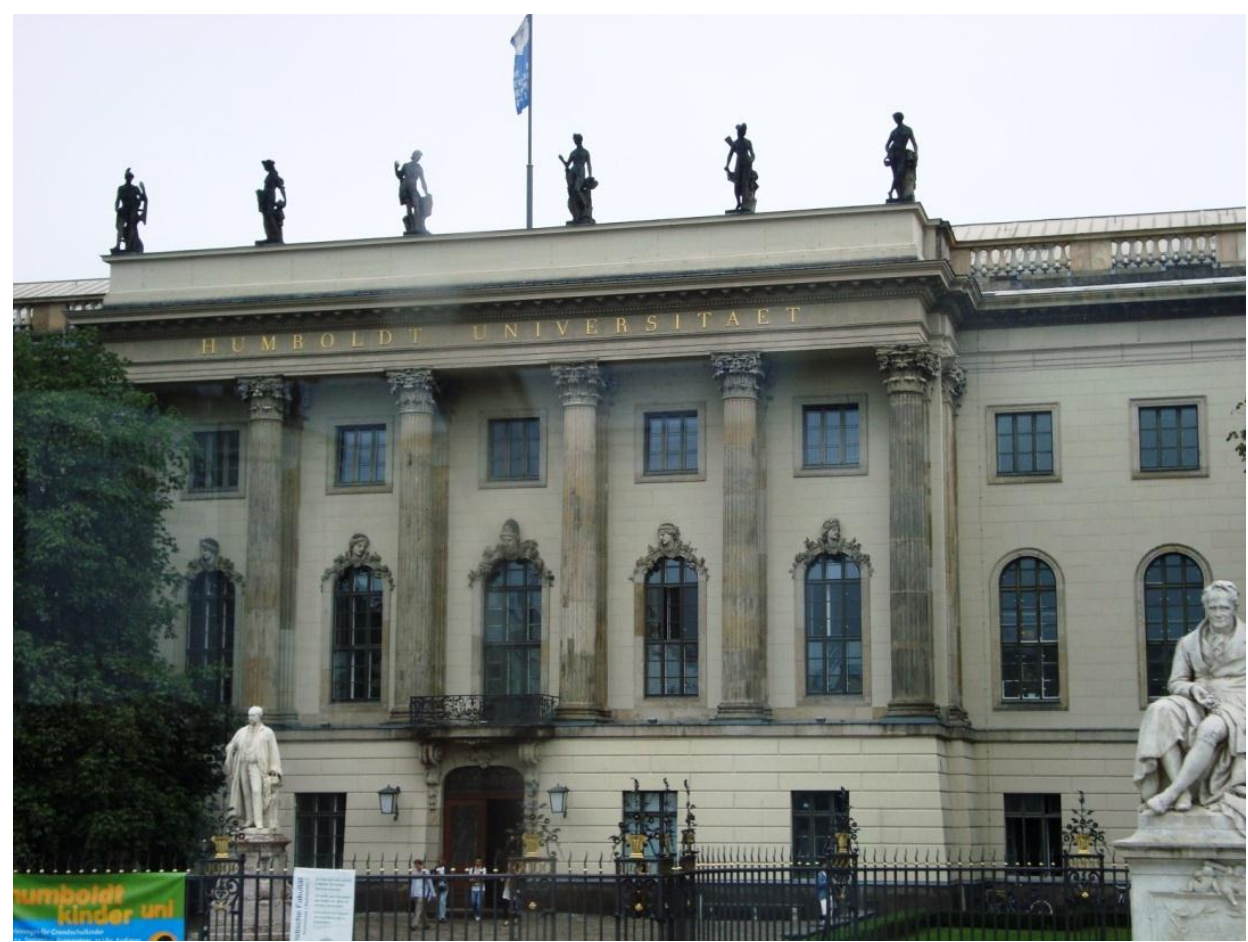

Universidade estatal fundada em 1810, em Berlim. O humanista Alexander von Humboldt era irmão do naturalista Wilhelm von Humbold que viajou pela América hispânica. O fundador foi o primeiro a enfatizar o ensino teórico vinculado à pesquisa prática. Foto da autora, 2012.

No início do século XIX, Wilhelm Von Humboldt, irmão do naturalista que viajou pela América Latina, explicou a linguagem humana como um 
sistema formado por regras, muito além de uma mera coleção de palavras e frases aleatoriamente compostas. Ele também é considerado o pai do sistema educacional alemão, além de ter fundado, em 1810, a primeira universidade de Berlim com um projeto pedagógico que influenciou as demais instituições superiores da Europa. Ele considerava que as instituições científicas só se justificam com programas, cursos e projetos que: "convergem para o enriquecimento da cultura moral da Nação. Em outras palavras, a organização interna das instituições científicas superiores se caracteriza pela combinação de ciência objetiva e formação subjetiva".

Autonomia e cooperação entre professores e estudantes seriam os princípios dos estudos universitários que, aliados à pesquisa, promovem os estudos e a pesquisa científica. Os docentes tanto contribuem na formação de novos profissionais pelo ensino como pelos grupos de pesquisa vinculados às instituições públicas e privadas. Humboldt ainda considerava que os professores deveriam ter compromissos como a nação, pois a universidade, mais do que a escola seria um fórum para debates. Já na escola, o aluno deve se preparar para exercer uma profissão e assim, contribuir para a sociedade, ser autodidata e concentrar-se em alguns temas abordados sob diversas perspectivas. Além das matérias, os alunos deveriam ter atividades experimentais e extracurriculares como visitas pedagógicas a museus, vida cultural em teatros e passeios a rotas temáticas, em que interagem tanto com o mundo lúdico, como com o industrial. Há quase 400 instituições de ensino superior, técnicas e universitárias que disputam níveis de excelência na pesquisa de ponta com canais científicos dentro e fora do país. Apesar de o governo investir milhões no ensino superior, as universidades públicas agora cobram uma taxa de 500 euros por semestre. As cinco maiores universidades são: Münster, de Mainz (Mogúncia), a Uni-Hamburg, a de LMU Munique e a de Colônia, com 34.268 mil a 41.782 mil estudantes inscritos; centenas de outras atendem a diversas vocações e objetivos profissionais:

- A Universidade Técnica (TU) e as Escolas Superiores Técnicas (TH) atendem a interessados em ciências, com cursos de engenharia, ciências naturais, medicina, economia e administração. 
- Cerca de 200 Universidades de Ciências Aplicadas (FH) oferecem cursos paralelos ao saber teórico, com semestres de estágio prático para obter experiência profissional (menos graduação em medicina e direito e sem programa de doutorado).

- Cinquenta Escolas Superiores de Artes com cursos música, artes e cinema, e o requerimento é um teste de capacitação específica. O estudo dá liberdade para que o discente siga o seu talento e no curso de música há muito estudantes estrangeiros.

- Cem universidades privadas enfatizam a formação prática dos estudantes com grupos de alunos, cursos de curta duração e bons contatos no setor econômico. As taxas variam entre 1800 a 4700 por semestre.

Várias titulações como a graduação - Bachelor, de três a quatro anos cujo pré-requisito é a conclusão do ensino médio alemão, o Abitur ou Carta de Admissão, caso o discente seja de fora do país. Em alguns dos seis mil cursos aulas são ministradas em inglês, com a presença de estudantes alemães. O Máster exige conclusão do Bachelor, de dois até quatro semestres, para aprofundar o conhecimento como especialista ou ampliá-lo pela interdisciplinaridade. Há quarenta cursos de política aplicada para estudantes ou jovens profissionais de países em desenvolvimento, tais como energias renováveis ou hidrologia tropical para os quais o DAAD, Serviço de Intercâmbio Acadêmico Alemão, presente em vários países oferece bolsas.

O doutorado tem duração de três anos e atualmente há mais estrangeiros do que alemães ou residentes cursando, tamanha a demanda! Em 2009 havia novecentos programas com orientação ao pesquisador, trabalho em equipe e prática. Cursos de altíssimo nível oferecem pesquisas em institutos renomados como Max- Planck ou, Fraunhofer ou as associações Leibniz e Helmholtz. Na Universidade Stuttgart-Hohenheim a graduação em Bioprodutos e Bioenergia visa a produzir e processar plantas como matérias primas ou fonte energética. A Universidade Técnica de Braunschweig oferece o curso Trânsito e Mobilidade (bacharelado com mestrado) com foco interdisciplinar com docentes economistas, cientistas sociais, engenheiros civis e da informação, dentre outros.

História \& Ensino, Londrina, v. 18, n. 2, p. 249-280, jul./dez. 2012 
Dentre as pós-graduações, pode-se fazer o Máster em Energia Renovável como o curso de três semestres da Universidade de Oldenburg onde se aprende desde força eólica a tecnologias alternativas. Ou em Economia Energética nas Universidades de Münster junto a de RWTH Aachen, com profissionais nas áreas de engenharia e ciências naturais. $O$ curso de Planejamento ambiental e engenharia ecológica na TU de Munique, enfoca tratamento de detritos e saneamento de águas poluídas; entre as disciplinas, gestão rural, biologia e relações públicas.

Entre as centenas de universidades distribuídas em 170 cidades alemãs, nove se destacam por estarem no ranking das universidades de excelência, tanto pelas condições de ensino e pesquisa; parcerias com setores privados e por contribuir com inovações práticas para a economia alemã e trabalhar com pesquisadores contemplados com Prêmio Nobel, conforme a seguir:

- Universidade Ludwig Maximiliano de Munique, fundada em 1473, é uma das maiores do país com 150 cursos que abrangem as áreas de humanas, biomédicas e ciências naturais em 18 faculdades, 700 professores, com 42 mil estudantes dos quais 17\% são estrangeiros. Ainda na capital bávara, onde fica o maior museu de ciência e tecnologia do país, a Universidade Técnica (TU), de 1868, tem doze faculdades com 127 cursos, 400 professores e 21 mil alunos (um quarto de estrangeiros) que participam do ensino e de pesquisas em ciências naturais e biológicas, engenharia e medicina. É uma universidade empresarial cujas verbas são garantidas mediante a cooperação econômica com o setor industrial como a automobilística BMW.

- Universidade de Constança, de 1966, às margens do lago fronteiriço com Áustria e Suíça alemã, contempla dez mil alunos É uma das melhores do país com quarenta cursos nas áreas das ciências naturais, humanas, jurídicas, econômicas. O seu conceito gira em torno do aprendizado fomentando jovens cientistas como centro de vanguarda para pesquisadores de ponta em química, biologia, informática e ciências da informação. Também perto da Perto da Suíça e da França, está a AlbertLudwigs-Universität, uma das universidades alemãs mais antigas, fundada 
em 1457. Abriga faculdades de teologia, medicina, direito e filosofia, com onze faculdades e sempre se considerou um elo entre as ciências naturais, sociais e humanas.

- Karlsruhe Institut für Techologie - KIT, desde 2006 é a fusão da universidade técnica mais antiga do país (1825) com o Centro de Pesquisa Karlsruhe Ltda, fundado em 1956, formando uma instituição de excelência em engenharias, ciências econômicas e naturais. Contempla 277 professores, 18 mil estudantes, onze faculdades e 43 cursos inclusive sobre mudança climática.

- Ruprecht-Karls-Universität de Heidelberg, fundada em 1386, é a mais antiga com excelente ensino e pesquisa, a primeira Liga Internacional de Universidades. Tradicionalmente concentra-se nas áreas humanas, mas é nas ciências naturais que abre o leque para cursos de odontologia e medicina humana, com pesquisas em biologia molecular e câncer. Totaliza, cerca de 30 mil estudantes, um quinto deles formados por estrangeiros, 146 cursos em treze faculdades com 380 professores.

- A Rheinisch-Westfälische Technische Hochschule - RWTH de Aachen na fronteira entre Bélgica e Holanda, destaca-se pelos engenheiros mecânicos e eletrotécnicos. Para consolidar a sua posição de vanguarda, aposta no fortalecimento das ciências naturais e na interdisciplinaridade dos cursos de engenharia. A cátedra mais recente pesquisa combustíveis feitos sob medida, a partir da biomassa.

- Georg-August-Universität de Göttingen, fundada na Baixa Saxônia em 1737, oferece 124 cursos como bioinformática, ciências biológicas e neurológicas moleculares. Dos 24 mil estudantes, $11 \%$ são estrangeiros; Com o lema "Göttingen: Tradição - Inovação - Autonomia", os acadêmicos atuam em centros de pesquisa de excelência como os institutos Max Planck, a Academia das Ciências de Göttingen, o Centro Alemão dos Primatas e a sucursal do Centro Alemão de Navegação Aérea e Espacial; desde a fundação mais de quarenta receberam Prêmio Nobel.

A Universidade Livre de Berlim é uma das mais conhecidas apesar de fundada em 1949, pelo governo da recém-criada República Federal da Alemanha, no lado ocidental da cidade. Portanto, os professores 
universitários visam a repassar conhecimento e tecnologia para formar futuros profissionais capazes de assumir funções como líderes, tanto na indústria como na economia. O sistema universitário alemão consiste mais em palestras e seminários do que em ensino e suas aulas regulares, pois fomentam a aprendizagem do discente, discutir e analisar projetos, além de aplicá-los em oficinas e laboratórios.

Os professores atendem às demandas do mercado e prestam consultoria a empresas que, por seu turno, financiam projetos de ponta nas universidades. A disseminação dos saberes em diversas publicações e a sua aplicação na melhoria material da sociedade justificam a alta tecnologia alemã. Os estudantes, por sua vez, participam dos centros de pesquisa alemães onde pós-graduados desenvolvem pesquisas e orientam os demais nos trabalhos científicos e invenções de produtos.

\section{Considerações gerais}

A preocupação com o ensino ocorre em vários níveis, a começar pela família onde, desde cedo, a criança aprende a participar do meio em que vive e interage com jogos e brincadeiras, com pais a lerem estórias infantis para os pequenos, habituando-os à leitura antes de dormir. A segunda etapa da educação formal, após o ensino fundamental, oferece escolhas ao aluno de seguir um ofício em escolas profissionalizantes ou se concluir o Abitur com vistas ao ingresso universitário. Também importa a educação não formal disponibilizada de maneira caleidoscópica, em várias formas e cores em visitas a museus não só históricos como também de várias temáticas, muitos deles interativos.

A frequência em jardins zoológicos e botânicos, em parques temáticos de cunho lúdico, ecológico, artísticos ou técnicos, ou simples labirintos e brinquedos, despertam o interesse pelas ciências. Além do mais, livros infanto-juvenis e jogos promovem a imaginação e o raciocínio, ou seja, vivencia-se cultura dentro de casa, em instituições ou mesmo nos espaços públicos como praças e calçadões. Afinal, diante das 
transformações aceleradas, é preciso esforço conjunto não só da escola, mas também, da família e da sociedade civil em torno da formação cultural e profissional.

O educador enfoca o ensino-aprendizagem para que o aluno saiba pesquisar, refletir, deduzir e elaborar novas ideias além do tradicional acúmulo de conteúdos. É melhor dedicar-se a poucos temas de cada vez que são analisados, aprofundados e, portanto apreendidos, não somente aprendidos para dar conta de inúmeras provas bimestrais como nas universidades brasileiras. Ao final de um curso universitário de humanas, o estudante escolhe as áreas em que prefere ser examinado, além de apresentar uma monografia em nível do que seria o mestrado aqui no Brasil. Também visitam dois cursos que em geral são correlatos, como Musicologia e Matemática, História e Germanística.

Para os acadêmicos, a atividade intelectual se aprimora mediante intercâmbio de saberes assim como de experiências, em contínua cooperação e incentivo mútuo, além de abordarem a ciência de modo aberto, com pesquisas que visam soluções contínuas. Enquanto na escola há transmissão de conhecimento previamente estabelecido, na universidade o relacionamento entre professores e alunos tem como objetivo, o desenvolvimento científico-acadêmico. Por outro lado, a atividade intelectual só progride quando há cooperação entre os membros de uma equipe a ponto de contagiar os demais. Os governos estaduais devem manter as escolas equipadas para preparar os alunos a entrar nas instituições acadêmicas superiores, de modo que preparem a transição de aluno para acadêmico afim de que esteja apto para se desenvolver por si mesmo.

\section{Referências Bibliográficas}

BANDEIRA, M. Do ideal socialista ao socialismo real. A reunificação da Alemanha. São Paulo: Ensaio. 1992. 
BÖSCH, B. (Org.). Historia da Literatura Alemã. São Paulo; EDUSP, 1967.

CAPDEVILLE, G. Os sistemas escolares alemão, inglês e francês e a formação de seus profissionais. Aberto, Brasília, ano 14, n. 64, out/dez 1994.

COLLINSON, P. A Reforma. Rio de Janeiro: Objetiva, 2006.

DUPEUX, L. Historia Cultural da Alemanha. Rio de Janeiro: Civilização Brasileira, 1992.

FÜHR, C. Deutsches Bildungswesen seit 1945. Bonn: Inter Nationen, 1996.

GADAMER, H-G. O problema da consciência histórica. Rio de Janeiro: Ed.FGV, 1998.

HINZEN, H. Educação de adultos na educação ao longo da vida: desenvolvimentos atuais e interdependentes na Alemanha e na Europa, a caminho da VI CONFIFEA. Revista Brasileira de Educação, vo. 14, n. 41, Rio de Janeiro, Maio-Agosto, 2009.

IVORY, M. Guia de Viagem - Alemanha 9 ed. São Paulo: Abril Cultural, 2008 LENZ, S. E. Alemães no Rio de Janeiro (1815-1866). Bauru, SP: EDUSC, 2008.

MAN, J. A revolução de Gutenberg. Rio de Janeiro: Ediouro, 2004.

PAHLEN, K. História Universal da Música. São Paulo, Ed. Melhoramentos, 1963.

RECKER, M-L. Geschichte der Bundesrepublik Deutschland. München: Beck, 2002.

SOMMER, T. (Org.). Leben in Deutschland. Köln: Kipenheuer Witsch, 2004.

VIZENTINI, P. As Guerras Mundiais (1914-1945). Porto Alegre: Leitura XXI, 2003.

\section{Internet}

http://rio.daad.de.video/video.htm

www.alemanja.org

www.deutsche-welle.de

Recebido em 29 de Novembro de 2012. Aceito em 29 de Dezembro de 2012. 